\title{
HOSPITALITAS DALAM MEWUJUDKAN RELASI YANG BAIK ANTAR UMAT BERAGAMA
}

\author{
Resvin Tapparan \\ Institut Agama Kristen Negeri Toraja \\ Resvintapparan12@gmail.com
}

\begin{abstract}
This paper shows how to create good relations between fellow religious communities. Then each religion has its own uniqueness, which differentiates one religion from another. However, there are also those religions that have a lot in common as well as great potential that can be developed to build the nation and state. In essence, religious pluralism contains the potential for conflict, as well as the potential to build cooperative relationships. It lies in the importance of regulating religious life in a community or country. Then it is very important when in a problem there is always a way to solve the problem, and to be able to solve various problems of religious life, when facing problems between religious communities it is necessary to show tolerance and mutual respect in making every decision.
\end{abstract}

KEYWORDS: hospitality, realizing, relations, between people, religions.

\begin{abstract}
ABSTRAK: tulisan ini memperlihatkan tentang bagaimana cara mewujudkan hubungan yang baik antar sesama umat beragama. Kemudian setiap agama memiliki keunikannya masing-masing, yang saling membedakan antara satu agama dengan agama lainnya. Namun demikian, agama-agama tersebut ada juga yang memiliki banyak kesamaan sekaligus potensi besar yang dapat dikembangkan untuk membangun bangsa dan negara. Pluralisme agama pada hakikatnya mengandung potensi konflik, sekaligus mengandung potensi untuk membangun hubungan kerjasama. Itu terletak pada pentingnya pengaturan kehidupan beragama dalam suatu komunitas atau negara. Kemudian sangatlah penting ketika dalam sebuah masalah selalu ada cara yang di lakukan untuk membuat pemecahan masalah tersebut, dan mampu menyelesaikan berbagai persoalan kehidupan beragama, ketika di dalam menghadapi masalah antar umat beragama maka perlu menunjukkan sikap toleransi dan saling menghormati dalam mengambil setiap keputusan.
\end{abstract}

KATA KUNCI: hospitalitas, mewujudkan, relasi, antar umat, beragama. 


\section{Pendahuluan}

Kemajemukan merupakan sebuah dari keniscayaan yang tidak dapat untuk terelakkan dalam kehidupan umat manusia. Adanya kemajemukan, sehingga itu merupakan sesuatu yang patut untuk di syukuri. Kemudian dalam hal ini seringkali terjadi kesalapahaman dalam memahami agama yang dapat berpotensi menimbulkan konflik antara umat beragama. Dari berbagai macam konflik tersebut sehingga bisa mengancam keutuhan sekaligus relasi antara umat terutama bila kemajemukan tersebut tidak di sikapi dan di kelola secara baik. ${ }^{1}$

Mewujudkan relasi yang baik selalu menjadi sentral pembahasan di tengah interaksi antara umat beragama. Isu yang sering terjadi menjadi pembahasan yang menarik oleh karena seringkali terjadi benturan yang di sebabkan oleh kesalahpahaman antar pemeluk agama. Oleh karena adanya kesalahpahaman tersebut terkadang sering di sebabkan oleh interpretasi, tanggapan, serta tindakan yang tidak perlu di lakukan oleh satu pemeluk agama terhadap pemeluk agama lain. tentu segala tindakan tersebut di anggap telah melewati koridator atau batas-batas sensitive terhadap agama yang bersangkutan. ${ }^{2}$

Suatu identitas yang melekat pada diri seseorang tampaknya sangat mempengaruhi penilaian dan cara pandang terhadap orang-orang di sekitarnya (termasuk agama yang di anut oleh orang tersebut). Dalam menjalin hubungan yang baik antar umat beragama maka perbedaan haruslah kita terima dan tidak untuk di hindari. Dari adanya perbedaan inilah yang harus di jadikan sebagai wujud adanya relasi yang baik antar sesama. ${ }^{3}$ Kemudian di dalam kerukunan hidup umat beragama khususnya dalam masa-masa terakhir pemerintahan Orde Baru mencapai titik jenuh. Hal itu sangatlah jelas kelihatan dalam bentuk kerusuhan sosial yang paling tidak di picu oleh perbedaan agama, atau mungkin lebih tepat agama-agama

\footnotetext{
${ }^{1}$ Musyarif et al. Kerukunan Umat Beragama di Kabupaten Tana Toraja (Parepare: IAIN Parepare Nusantara Press, 2019), 1-2.

${ }^{2}$ Ibid

${ }^{3}$ Yohanes K. Susanta, "Hospitalitas Sebagai Upaya Mencegah Kekerasan dan Memelihara Kerukunan Dalam Relasi Islam-Kristen di Indonesia," Societas Dei 2, No. 1 (April2015): 283.
} 
di pakai secara keliru oleh beberapa orang tertentu untuk memenuhi ambisi politik mereka. 4

\section{Tujuan dan Manfaat}

Tujuan dari adanya wujud relasi yang baik antar umat beragama maka akan ada toleransi, saling pengertian, saling menghormati, menghargai kesetaraan dalam pengamalan ajaran agama dan kerjasama dalam kehidupan bermasyarakat, berbangsa dan bernegara. Kemudian dalam mewujudkan relasi yang baik antar umat beragama merupakan sebuah inti dari kerukunan nasional, oleh karena itu mari kita menjaga relasi umat beragama karena itu sangat penting, baik itu relasi umat internal maupun antar umat beragama.

\section{Pembahasan}

\section{a. Kerukunan antar umat beragama: Perspektif Teologis}

\section{1) Umat manusia sebagai keluarga besar Allah}

Dalam pembahasan tentang umat manusia sebagai keluarga besar Allah perlu di awali dengan pembahasan tentang pengertian kerukunan. Perkataan rukun didalam bahasa Indonesia menunjukkan bahwa adanya hubungan yang baik, adanya hubungan yang serasi, selaras maupun seimbang antarpribadi dan golongan yang ada dalam masyarakat. Dalam hubungan ini walaupun mengakui adanya perbedaan secara hakiki tetapi yang tetap menonjol bukanlah benturan dan konflik, melainkan adalah kedamaian, kesejukan, ketertiban dan keamanan berupa gejala hidup yang dominan, karena melalui perbedaan itu mereka saling memberi, saling memperkaya, bahkan saling melengkapi. Seluruh umat manusia adalah sebuah keluarga besar Allah. Hal ini mengingatkan pada pengertian gereja sebagai persekutuan orang percaya dan Allah dalam Kristus Yesus adalah Bapak seluruh penduduk bumi yang di ciptakan-Nya, sebagai tempat hunian (rumah) umat manusia yang adalah keluarga besar Allah. Dalam

\footnotetext{
${ }^{4}$ Yewangeo. Agama dan Kerukunan (Jakarta: Gunung Mulia, 2009), 42.
} 
iman Kristiani hubungan kasih sebagai keluarga antara Allah dan manusia merupakan hal yang sangat sentral dan hakiki. ${ }^{5}$

\section{b. Kerukunan Hidup Umat Beragama sebagai Persoalan}

Secara kategoris orang menolak bahwa yang sedang terjadi di Indonesia itu adalah konflik antara umat beragama. Secara resmi pemerintah mengemukakan bahwa kesenjangan ekonomilah yang menjadi penyebab dari kerusuhan. Namun tidak dapat juga di sangkal bahwa dalam setiap kerusuhan itu terdapat juga nuansa-nuansa keagamaan di dalamnya. ${ }^{6}$

Kemudian sering juga terjadi kekerasan yang bernuansa agama yang di tunggangi oleh kepentingan politik. Dalam hal ini kekerasan sendiri juga bisa terjadi karena adanya akar kebencian yang tertanam di antara pemeluk agama yang berbeda. Kebencian ini yang terjadi di antara para penganut agama memang sungguh ada bahkan di rasakan. Seperti yang di katakan oleh Musdah Mulia "provokasi itu tidak akan berhasil jika tidak ada kebencian. Sedikit provokasi saja dengan mudah akan membakar perilaku egresif terhadap pemeluk agama lain. ${ }^{7}$

Dalam mewujudkan relasi yang baik antar umat beragama maka sangat penting bagi gereja untuk membangun relasi yang ramah tamah. Mewujudkan sikap sebagaimana yang Yesus tunjukkan yaitu melawan kekerasan tidak sama dengan sikap yang pasif, tidak peduli, mencari aman, pasrah dan lain sebagainya. Justru, perjuangan itu tanpa kekerasan perlahanlahan akan menghadirkan harmoni. Lalu, gereja juga perlu untuk mengembangkan dan menggemakan kembali apa yang di sebut tentang teologi keramahtamahan (hospitalitas). ${ }^{8}$

\section{c. Hospitalitas}

\footnotetext{
${ }^{5}$ Weinata Sairin, Kerukunan Umat Beragama Pilar Utama Kerukunan Berbangsa (Jakarta: Gunung Mulia, 2006), 15.

${ }^{6}$ Yewangeo. Agama dan Kerukunan (Jakarta: Gunung Mulia, 2009), 43.

${ }^{7}$ Yohanes K. Susanta, "Hospitalitas Sebagai Upaya Mencegah Kekerasan dan Memelihara Kerukunan Dalam Relasi Islam-Kristen di Indonesia," Societas Dei 2, No. 1 (April2015): 291.

${ }^{8}$ Ibid. Hal. 302-303.
} 
Hospitalitas merupakan cara untuk menjalin persahabatan dengan orang lain dan itu merupakan tanggung jawab dari setiap orang. Hospitalitas juga bukan sekadar konsep yang harus kita miliki melainkan untuk kita praktekkan dalam relasi dengan orang lain. hospitalitas bukanlah tanpa menanggung sebuah resiko. Namun hendaklah di ketahui bahwa seperti seorang tuan rumah yang membuka pintu rumahnya untuk orang asing, lalu ada kemungkinan bahwa orang asing tersebut justru akan mengambil kesempatan yang lain dari kebaikan sang tuan rumah. ${ }^{9}$

Sebagai makhluk sosial manusia pasti akan selalu saling membutuhkan satu dengan yang lain, dan perlu untuk membutuhkan relasi yang baik antarindividu. Relasi yang baik pun harus di wujudkan antar umat beragama dan dapat di bangun mulai dari keramahan, keterbukaan, kelemahlembutan, dan penerimaan antara satu individu dengan individu lainnya. Hal inilah yang di sebut dengan hospitalitas. Hospitalitas menjadikan manusia semakin erat satu dengan yang lainnya. Melalui sikap hospitalitas ini maka bisa menjadikan orang tidak membeda-bedakan orang lain. hospitalitas memiliki hubungan yang erat dengan relasi manusia satu dengan yang lainnya. Hospitalitas di dasari dari bentuk cinta kasih bagi semua orang. ${ }^{10} \mathrm{Hal}$ ini juga di wujudkan dalam kehidupan masa kini, sebagai manusia tentunya sangat penting dalam mewujudkan kasih terhadap sesama umat beragama, seperti halnya dalam keadaan pandemic Covid-19 saat ini, orang-orang harus mempunyai rasa empati terhadap sesama sebagai sikap hospitalitas di setiap masa kehidupan. Wujud empati harus di wujudkan di tengah pandemic ini dengan cara menunjukkan sisi kemanusian manusia di tengah krisis pandemic tanpa harus memandang perbedaan. Iman bukan hanya relasi secara vertical akan tetapi juga merupakan perwujudan kasih

\footnotetext{
${ }^{9}$ Ibid. Hal. 304\&306.

${ }^{10}$ Daniel Fajar Panuntun. Nilai Hospitalitas dalam Budaya (Jakarta: Gunung Mulia, 2020), 28-29.
} 
terhadap sesama manusia yang di buktikan melalui empati hospitalitas di tengah pandemi. 11

\section{Kesimpulan}

Mewujudkan relasi yang baik antar umat beragama sangatlah penting, meskipun usaha dalam menjalin sebuah relasi dengan sesama tentunya bukanlah suatu hal yang mudah, tetapi hal itu memang harus di lakukan. Kerukunan di antara umat beragama harus pula di pahami sebagai pencerminan dan perwujudan kasih setia Allah dalam Yesus Kristus dalam persekutuan dengan Roh-Nya yang kudus.

\footnotetext{
${ }^{11}$ Daniel Fajar panuntun, "Hospitalitas Kristen dan Tantangannya di Tengah Pandemi Covid-19," Jurnal Multikultural \& Multireligius 19, No. 1 (Oktober 2020): 79-80.
} 


\section{DAFTAR ACUAN}

Musyarif, Hasnani Siri, Caerul Mundzir. Kerukunan Umat Beragama di Kabupaten Tana

Toraja (Parepare: IAIN Parepare Nusantara Press, 2019).

Susanta, Yohanes K. "Hospitalitas Sebagai Upaya Mencegah Kekerasandan Memelihara Kerukunan Dalam Relasi Islam-Kristen di Indonesia," Societas Dei 2,No. 1 (April 2015).

Yewangeo. Agama dan Kerukunan (Jakarta: Gunung Mulia, 2009).

Panuntun, Daniel Fajar. Nilai Hospitalitas dalam Budaya (Jakarta: Gunung Mulia, 2020).

Panuntun, Daniel Fajar, "Hospitalitas Kristen dan Tantangannya di Tengah Pandemi Covid-19," Jurnal Multikultural \& Multireligius 19, No. 1 (Oktober 2020). 